This is the Authors' Original Manuscript of an article, whose final and definitive form, the Version of Record, will be published by Current Issues in Tourism.

\title{
Destination Competitiveness: Evidence from Bali
}

Wei Lee Chin (Universiti Brunei Darussalam), Janet Haddock-Fraser (Manchester Metropolitan University) and Mark P. Hampton (University of Kent) ${ }^{1}$

\section{Corresponding Author:}

Kent Business School, University of Kent, Canterbury CT2 7PE, UK.

Email: m.hampton@kent.ac.uk.

Tel: $+44(0) 1227827726$

\begin{abstract}
Within the dynamic global tourism industry, understanding the reasons for a destination's competitiveness is essential in order to enhance its performance, facilitate more effective destination management, and inform its overall sustainable economic development. This paper applies Kim and Wicks' (2010) tourism cluster development model to Bali - a small, mature destination in the developing economy of Indonesia. It demonstrates that there are complex relationships between: (i) cluster actors; (ii) barriers preventing effective networking; and (iii) the significance of these interactions for the local host community. This paper contributes to the debate by addressing new and different attributes and actors such as transnational corporations (TNCs), universities, and the concept of co-opetition, as being significant attributes in Kim and Wicks' initial model. Through a qualitative approach involving $\mathrm{n}=23$ semi-structured interviews,
\end{abstract}


this paper illustrates intricate issues and relationships that are identified in Bali, a small mature destination. Purposive sampling methods were employed to generate a range of key stakeholders who informed our understanding of 'cluster actors' in Kim and Wicks' terms. The systematic examination of these key tourism elements provides a detailed analysis of the destination's strengths and weaknesses, and a more nuanced understanding of what facilitates a destination's competitive position.

Key words: destination competitiveness; cluster theory; impacts; island tourism; Indonesia

\section{Introduction}

Global tourism's continuing expansion as exemplified by rising international arrivals and number of new destinations suggests that understanding destination competitiveness is an essential component of effective destination management and planning. Establishing the factors which enhance destination competitiveness has been an enduring theme in the tourism literature leading to a proliferation of destination competitiveness studies (Croes 2011; Crouch and Ritchie 1999; Dwyer and Kim 2003; Enright and Newton 2004). Destination competitiveness has become a significant topic for researchers, governments and policymakers, since destinations are keen to establish their competitive position (and perceived economic benefits) as well as to understand their key differentiators. However, limitations in the literature are evident regarding the comprehensiveness and universality of destination competitiveness models as applied to regions such as the Asia Pacific. Despite the continuous growth of tourism in the Asia Pacific region, to the authors' knowledge there is only one tourism destination competitiveness study that examined specific case studies in this region - Enright and Newton (2005) - who discussed 
the possibility of different importance/ranking in competitiveness attributes across three locations but did not include Bali. Our paper therefore addresses the relevance of Kim and Wicks' (2010) conceptual model determining destination competitiveness factors for a small mature destination in South-East Asia.

As part of this, we explore the elements within Porter's Diamond (reformulated by Kim and Wicks); the relationship of cluster actors (Figure 1); and how such factors affect the competitiveness of a small developing destination. This analysis illustrates complex relationships and linkages between cluster actors; barriers preventing effective networks; and highlights the significance of those interactions, which leads to wider understanding of the socioeconomic implications for the host community. Our analysis enables tourism policymakers to develop a more comprehensive understanding to enable strategic planning; helps identify destination strengths and weaknesses; as well as identification of barriers to progress.

The paper is divided into six sections. First, we explore and critique the key literature relating to competitiveness models, rationalising the application of the Kim and Wicks (2010) model for this research. Second, a description of tourism in Bali is presented, followed by the methodology and research approach used. The main findings are analysed, highlighting destination competitiveness issues specifically for Bali, followed by a discussion. The paper concludes noting how this framework provides academics and policymakers with a useable tool to understand certain complexity, destination dynamics, and main actors.

\section{Literature Review of Competitiveness models}

Most academic work on destination competitiveness models (Dwyer and Kim 2003; Crouch and Ritchie 1999; Enright and Newton 2004, 2005; Hudson, Ritchie and Timur 2004) incorporates 
Porter's National Diamond (1990) into their destination competitiveness frameworks enabling the multiple competitiveness factors to be considered. Although the inclusion of both tourism and business-related factors from existing approaches has contributed to the debate, we assert here that research gaps remain concerning the significance of relevant attributes, especially in rapidly developing economies.

Previous studies examined different aspects of competitiveness. Dwyer, Forsyth and Rao (2000) published a comprehensive study on tourism price competitiveness noting the relationship between price and competitiveness. Go and Govers (1999), observed that product quality has a direct relationship with the amount paid. Emphasis was also put on visitor needs and achieving business goals as they are closely linked to maintaining quality standards - essential for achieving competitiveness in international markets (Go and Govers, 2000). Similarly, Hassan (2000) focussed on environmental features related to tourism and the magnitude of sustaining growth by identifying key characteristics of market competitiveness. Crouch and Ritchie (1995, 1999) discussed the tourism competitiveness model in the context of national economies and concentrated on long-term economic wealth as a guideline for sustainable growth. They claimed that “to be competitive, a destination's development of tourism must be sustainable, not just economically and not just ecologically, but socially, culturally and politically as well” (Ritchie and Crouch, 2000, p5). Conversely, Heath (2003) disagreed with the comprehensiveness of existing models, arguing that the issues surrounding the competitiveness phenomenon were not fully taken into consideration, and that success drivers like people, communication and information management required more attention.

Although an extensive literature regarding destination competitiveness exists, including a recent, wide-ranging review by Pearce (2014), this paper concentrates here on attributes selected 
from Kim and Wicks' (2010) Tourism Cluster Development model. Their model incorporates new actors such as transnational corporations (TNCs) and universities, and the concept of coopetition within clusters - all of which can be applied to small developing economies. Kim and Wicks' model is somewhat conceptual being at a high level of abstraction and to the authors' knowledge, despite its potential contribution, it has not yet been applied to any specific case study. This paper is the first attempt to use it to analyse a mature destination such as Bali. A more thorough justifications of Kim and Wicks' model is highlighted in following sections.

\subsection{Cluster Theory}

Cluster theory is highlighted in Kim and Wicks' (2010) model and shows the significance of the relationships between clusters, their network, roles and responsibilities and how this affects a destination's overall competitiveness. The cluster concept is often seen as creating competitive advantage by tourism policymakers aiming for sustainable development. The industrial cluster phenomenon - and how such networks can succeed - has been observed for some time and cluster theory draws on the work of Marshall (1920) which considers how firms' geographical proximity creates positive externalities. Cluster theory is useful as it illustrates complex systems and intricate relationships between networks of small companies and other institutions in the fragmented tourism sector (Bernini, 2009). The complexity of networks involved in tourism usually engage a large number of providers from large corporations like luxury hotels to Small and Medium size enterprises (SMEs) such as bed and breakfast establishments or hawker stalls as well as other stakeholders who are not necessarily involved in tourism. Writers including Go and Williams (1993), Hall and Thomas (2004); Hall, (2005), Jackson and Murphy (2002), Michael (2003) and Moric (2013) have applied either cluster theory or the combination of cluster 
and Diamond theory to tourism. Arguably, one reason for cluster theory's wide acceptance is the way it highlights the effective use of networks, specifically, how intelligent use can take advantage of local collaboration and community participation, as well as high international status, through promoting network and business clusters (Jackson and Murphy, 2006). Kim and Wicks' model takes into account both cluster and Diamond theory to provide a better understanding of how both concepts can be used to analyse tourism competitiveness.

\subsection{Kim and Wicks' Tourism Cluster Development Model}

One useful insight from Kim and Wicks' model is their emphasis on the vital role of TNCs in tourism, especially in developing economies. Kalish (2001) and UNCTAD (2007) estimated that TNCs account for a high proportion (possibly over 80\%) of foreign direct investment (FDI) and ownership in tourism in the developing world. As globalisation has led to the emergence of countries (especially developing nations) playing a bigger role in the global trading system, the domestic economies of these destinations are consequently affected by TNCs. Their integrated approach was built on the work of Crouch and Ritchie (1999) and Dwyer and Kim (2003) to create the Kim and Wicks' Tourism Cluster Development Model. Their model synthesised theories including cluster theory; co-opetition; and added new key factors such as the TNCs' activities; all of which affect evolving destination competitiveness. Their model also emphasised the difference between the role of cluster actors and factors incorporated from Porter's Diamond model; and the interrelations between cluster actors illustrates the importance of collaboration, competition or any barriers hindering development of the (usually) fragmented tourism industry.

In Kim and Wicks' framework, new variables for developing economies were also included, particularly the significance of TNCs and FDI, since these economies are highly 
dependent on investment from developed countries. Their model also emphasised the importance of clusters and highlighted how each cluster actor works in terms of networking and interconnection. Cluster actors such as TNCs, destination management organisations (DMOs), government and companies are highlighted because of their significant interconnected networks as well as their contribution to national wealth. This was also noted by Schmitz (1999) and Nadvi (1999), who reiterated cluster theory's significance and the importance of collective efficiency where cluster actors' collaboration might allow higher chances of success for developing economies given the constant changes in global tourism. Cluster formation is also a powerful strategy for early development of companies as it assists the start-up process of small firms with combined synergies as well as collaboration (Schmitz and Nadvi 1999). 
Figure 1: Kim and Wicks (2010) Cluster Development model.

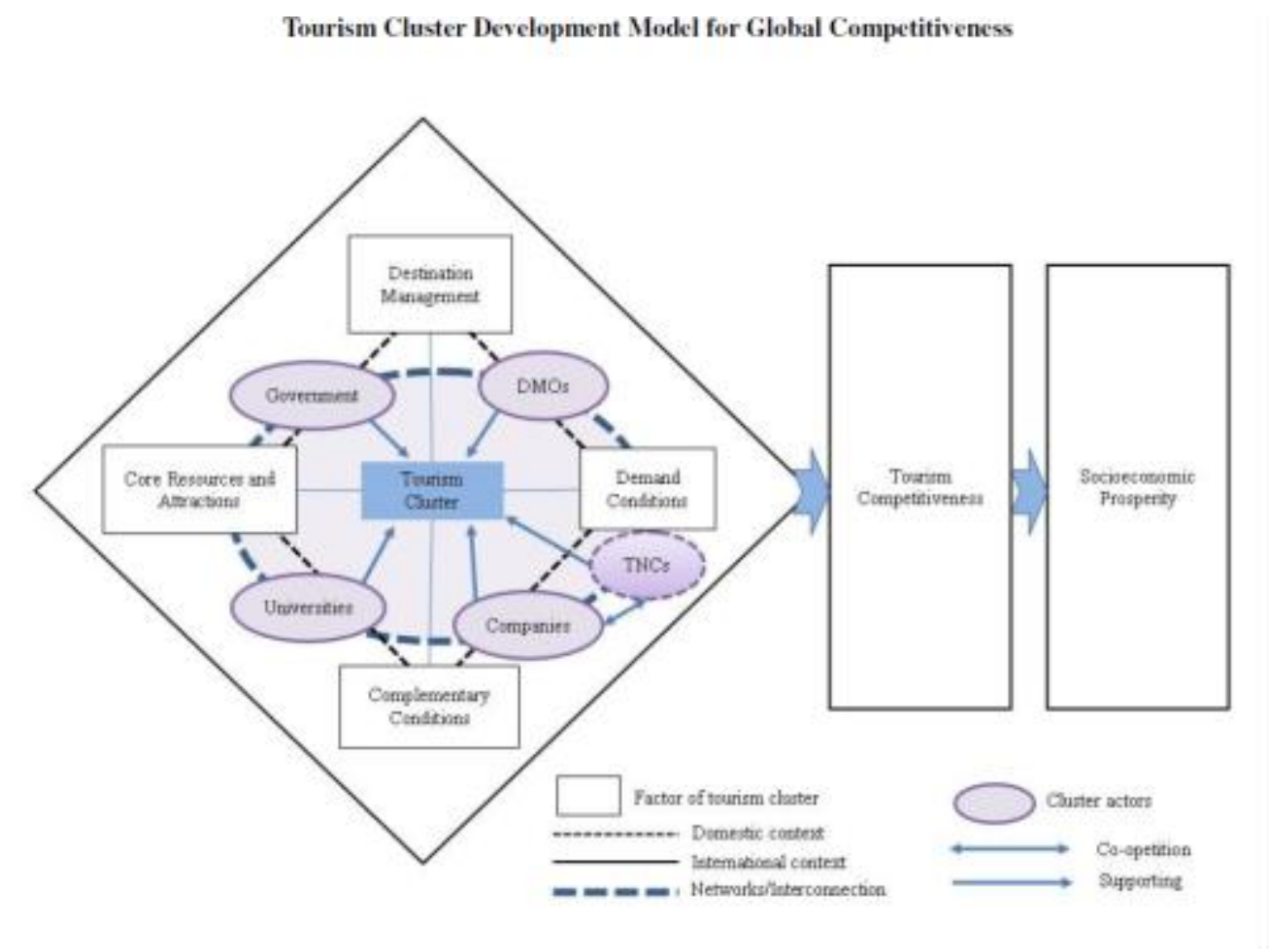

The model also highlights the separation of the conditions adopted from Porter's Diamond and the newly added cluster actors. Our paper explores all conditions adopted from Porter's Diamond and the newly added cluster actors, their interrelationship, the linkage between actors and how such factors could affect the competitiveness of a small destination like Bali. Cluster actors are claimed to bring competitiveness to destinations by ensuring co-operation between tourism clusters, and also ensuring effective functioning of actors such as small tourism-related companies. In addition, the inclusion of cluster actors such as DMOs encompasses other members such those from the public sector, non-governmental organisations (NGOs) and the private sector. Their interconnection and partnership in activities such as joint marketing or 
establishing and developing new strategic ideas for rebranding existing destinations, are significant for determining destination competitiveness. The inclusion of universities could also provide further technological research or enhance innovation.

Similarly, competition also exists within the tourism industry to enhance product quality, promote innovation and increase tourist satisfaction, as well as creating memorable experiences. Kim and Wicks argue that the function and impact of TNCs creates both opportunities for knowledge transfer, and competition with domestic firms to drive the destination towards greater competitiveness. Their model suggests that cluster-based development strategies should be considered by governments to improve destinations, as it facilitates greater collaboration as well as competition within cluster actors, which in turn, boosts competitiveness for less developed destinations.

The relationship between TNCs and other companies (Figure 1) demonstrates an exceptional relationship - 'co-opetition' - where each actor believes that all actors involved could work cooperatively, whilst at the same time competing fiercely with each other. Kim and Wicks argue that there are large numbers of developing countries that rely on TNCs and FDI for economic reinforcement and diversity; hence it should not be overlooked (see also Dunning 1993). In addition, the significance of TNCs and FDI in the tourist sector, especially in emerging destinations, has also been discussed in the UN Conference for Trade and Development (UNCTAD) due to many countries' high dependence on external investment (UN WTO, 2012). 


\section{Tourism in Bali}

\subsection{Early Tourism}

Bali, one of the most popular tourist destinations in South-East Asia, is located east of Java in the Indonesian archipelago. It is one of the 34 Indonesian provinces with a population of around 4.22 million (BPS, 2013). Tourism in Indonesia is overseen by the Ministry of Tourism and Creative Economy, but under decentralisation, the provincial government in Bali is responsible for local governance and legislation including most aspects of tourism planning.

Bali's international tourism began in the 1920s under the Dutch colonial administration; however it did not host large numbers until the 1970s (Picard, 1996). By then international tourism was seen by governments and international bodies such as the World Bank as a major driver of economic growth. International arrivals saw a dramatic increase from 30,000 in the 1970s to 1.5 million by 1994 making a significant contribution to employment and Gross Regional Domestic Product (Picard, 1996). Tourism development has also led to drastic changes in land use along Bali's South coast such as around Kuta. Rising real estate and land prices meant that once inexpensive beachfront areas in the former Kuta village became highly valuable for tourism. The fishing village of Kuta with a population of 9,000 became gradually transformed to a premier destination with 60,000 tourist arrivals in the 1980s (Hussey, 1989). However, Kuta grew in an ad hoc way as a 'bottom up' tourism development outside formal planning structures (Wall and Long, 1996). This created many opportunities for local people to start businesses, but the initially limited commercial activity and infrastructure that satisfied backpackers later proved insufficient to cope with the influx of mass tourists leading to infrastructural problems with traffic, sewage supply etc as a result of rapid, and unplanned tourism development (Connell, 1993). This was compounded as the Bali Master Plan in the 
1970s which effectively ignored the (then) small-scale unplanned tourism in Kuta. The Master Plan focussed on developing a large integrated resort at Nusa Dua on the south coast (Picard, 1996; Hampton, 2010). The increase in the development of high-end resorts in Nusa Dua has led to the concentration of the majority of tourists in the Southern part of Bali. This has also contributed to the increase in international mass ' $3 \mathrm{~S}$ ' tourism (sun, sea and sand). Besides beachbased activities, culture was also seen as a major tourism product building upon Bali's Hindu heritage of temples, dance and handicrafts. Ubud, a large village in the centre of the island, has become Bali's cultural and dance 'capital', boosting local pride in local Hindu culture and is used to promote cultural tourism (Hitchcock, 2000).

In 1998 tourism numbers increased again after the downturn associated with the first Gulf War in 1991. However, terrorist bombings in Bali in 2002 and 2005 dramatically illustrated destinations' vulnerability to terrorism and severely impacted Bali’s previously peaceful 'paradise' image. International tourist arrivals declined sharply and hotel occupancy fell from $70 \%$ to below $20 \%$ after the 2005 bombing (Hitchcock, King, and Parnwell, 2009). Despite some difficult years after the attacks, overall Bali's tourism industry continues to grow even in today's competitive era (Hitchcock and Putra, 2005; Henderson, 2003; Putra and Hitchcock, 2006).

\subsection{Present day Tourism}

Bali is Indonesia's primary tourism hub with 3.2 million international tourist arrivals in 2013 (Dinas Pariwisata Bali 2014). Key regional markets include Australia, China, Japan, Malaysia, Taiwan and South Korea. Other main markets include the UK, France, USA and Germany. Tourism contributes more than $65 \%$ of Bali's Gross Regional Domestic Product (approximately \$10.5 million) in 2012 (BPS, 2013) and employs an estimated 60\% of the island's labour force 
(directly and indirectly) (Picard, 2009). Average tourist expenditure per visit to Bali in 2009 was approximately $\$ 1,400$ - 1,900 and was estimated as contributing US\$ 2.7 billion in foreign exchange in 2009 towards the Balinese economy (BPS data).

Given tourism's influential role in the Balinese economy and associated social, cultural, environmental and other impacts, its academic literature has also increased. There is a growing body of work examining international tourism and its implications for Balinese culture and identity (for example see Picard, 1996; Minca, 2000, Ramstedt, 2012; Berger, 2013). The increasing pressure on the environment and the associated planning and land use issues have been analysed by Wall, 1998; Cole, 2012 and Cole and Browne, 2015 for example, whereas socio-economic aspects have been covered such as local entrepreneurship (Shaw and Shaw 1999; Dahles and Bras 1999; Hitchcock 2000) and the significance of the growing informal sector (Cukier and Wall 1994; Baker and Coulter, 2007).

With the continuous inflow of mass tourism, the success of Bali's tourism has led to increasing urbanisation and changing land use away from agriculture, growing amounts of traffic and waste needing disposal, and the island appears to be now exceeding its carrying capacity with further pressure in addition upon scarce water supplies especially in the South of the island (Cole and Browne, 2015). The rapid, uncontrolled, unplanned and virtually unregulated changes in Kuta and Sanur in particular were also observed by Baker and Coulter (2007). More recently, Bali's Environmental Agency noted that the island was generating 13,000 cubic metres of trash produced per day, that 700 hectares of land were being converted each year to hotels, roads and villas, and an estimated 300 litres of fresh water were consumed by each four-star room each day (reported in The Guardian, 2012). Despite the efforts of environmental groups to emphasise the increasing environmental problems and question tourism's sustainability, and the regional 
government's regulations to prohibit new developments in heavily developed areas, the local government approved the building of further infrastructure to host the 2013 Asia Pacific Economic Cooperation (APEC) Summit. A new hotel (Sofitel) in Nusa Dua was specially built to host the APEC meeting venues; several hotels underwent major renovations to increase their room capacity; the Benoa-Ngurai Rai-Nusa Dua toll road was built at a cost of Rp 2.5 trillion; the airport extension cost of Rp 2.8 trillion; and the Dewa Ruci under-pass was built costing Rp 148 billion. Although the environment was given some consideration to minimise negative environmental impacts, many hectares of mangrove forests were cleared (The Jakarta Post, 2013). The action approved by the local government had created a conflict of interest where the different priorities between central, regional/provincial and local governments were not solved.

External investors dominated Bali since the former Governor of Bali, Ida Bagus (19881998) was well known for favouring foreign investors and the interest of the Jakarta Conglomerates (Aditjondro, 1995). He was seen to be giving priority to foreigners for business opportunities although Jakarta companies could not be considered 'foreign' (Hitchcock, 2000; Hitchcock and Darma Putra, 2007). The perhaps most unpopular investment by foreign investors was the building of Pan Pacific Nirwana Bali resort within two kilometres of Tanah Lot, a sacred temple in Bali (Suasta and Connor 1999; Lewis and Lewis, 2009). Despite residents' opposition and the Hindu Religious Council issuing a decree to ban tourism facilities within the temple's sacred radius, the government approved the project regardless. An inequality of power distribution was clearly evident in Bali and this showed how uncontrolled development can result in skilful manipulation of the community by few dominant local developers (Brohman 1996; Wall and Long 1996). 
Indonesia's latest tourism strategy aims to double its tourist's arrivals by 2020 and has removed visa restrictions for 30 countries including China, the US and Germany but such actions might not be favourable to Bali. The governments marketing budget has surged up to $\$ 75$ million in 2015 and aims to promote several destinations, with Bali as one of the top priorities (Blomberg Business, 2015). The marketing budget is forecast to be spent on destinations such as Bali that are already attracting visitors in order to save the costs of creating newer destinations. Given that Bali appears to be already exceeding its carrying capacity, Indonesia's latest tourism strategy might need further consideration to include a more nuanced approach towards more balanced development across the wider archipelago. (This need to re-balance tourism and reduce Bali's predominance has been recognised in the literature since at least the early 1990s - see Connell, 1993 for instance).

\section{Methodology}

Bali was selected as an iconic destination for field work, involving an intense three week visit using a rapid rural appraisal type approach and qualitative data collection techniques (Chambers, 1983; Ellis and Sheridan, 2014). All of the paper's authors have extensive prior experience in tourism in this part of South-East Asia, and two authors have a long connection to Bali, what Pagdin (1989) calls 'pre-knowledge' of the field work location. Budget and logistical constraints meant that a longer period of field work was not possible on this project so that a rapid appraisal type approach was considered to be the most appropriate utilising the team's 'pre-knowledge' to maximise qualitative data collection in Bali. In terms of positionality, the authors intensively discussed the context of the project at the pre-fieldwork stage (such as during the creation of the interview protocols and in the preparation for going to the field). During the field work itself, as 
well as undertaking the main task of interviews, direct observations and other notes were detailed in reflective field journals, and then post-visit, comments and interview data were interrogated in light of emerging themes and possible contradictions. This echoes Dupuis' ideas (as elaborated in Cohen, 2013) of the importance of self-reflection in qualitative field work both before, during and afterwards in the production of 'stories', in this case, this particular research article.

During field work $n=23$ in-depth, semi-structured interviews were conducted during peak tourist season in Bali (June-July), and average interview duration was approximately 1.5 hours (See Appendix: Table 1 and 2 for respondent list and typology of stakeholder groups). Interviews took place in the Bahasa Indonesia language and then were translated on return from field work. Although translators were employed to translate interviews, one author is fluent in Bahasa Indonesia so that consistency of translation into English could reasonably be assured.

Interview respondents in Bali were selected using purposive sampling to generate a range of key stakeholders who would inform our understanding of 'cluster actors' in Kim and Wicks' terms. Stakeholders interviewed included small enterprise owners, vendors, locals, transport providers, NGOs, tourism academics and government officials. Nusa Dua, Legian, Denpasar (the capital), Kuta and Ubud were chosen as the interview locations given tourism's rapid development in those areas. Interviews also took place in Kintamani, a small village in the North of Bali. By interviewing respondents in regions experiencing rapid tourism growth as well as in those with more limited development, it provided valuable information on the dissonance between different stakeholders' voices.

Interview questions were created based on Kim and Wicks' Tourism Cluster Development Model. To ensure that all determinants and cluster relationships were included in the questions, a cross reference between the interview questions and the framework was done 
(Appendix: Table 3). Interviewees were selected through two initial gatekeepers: a leading development NGO working in Bali, and a tourism academic from Udayana University. Interviews were carried out with these gatekeepers and more contacts were made using the 'snowballing' technique. The contacts provided by the initial gatekeeper produced the first few respondents, who in turn were contacted, and thus provided further respondents. Contacting potential respondents recommended by previous interviewees led to further respondents, who thus made up the entire participant list. Specifically, the gatekeepers provided numerous academic and NGO contacts, who in turn recommended hoteliers, tour operators, local entrepreneurs, government officials (including those working in the Bali Tourism Board), as well as travel agencies. Snowballing introduced a variety of key stakeholders which was extremely useful for our research. The use of key gatekeepers helps overcome possible concerns about how representative the sample is. The stakeholders interviewed through the snowballing process were all pertinent to this research since the majority had relevant knowledge (academics, government officials) and some had innovation practices (entrepreneurs, hoteliers, tour operators, travel agencies), which all generated valuable information. Faugier and Sargeant (1997) argue that snowballing takes advantage of the identified respondents' social networks, which can be representative and highly useful for researchers by providing a set of potential contacts. The paper's authors, however, recognise that only a small number of interviews were undertaken with each type of stakeholder, and that this might be a limitation and could raise the issue of representativeness of our sample. However, sampling the population was essential given that it would have been unrealistic to even consider interviewing all hoteliers in Bali for instance. Also, researchers can face 'data saturation' where the results become repetitive and there is no need to continue interviewing once it is found that further interviews are adding little value to the 
findings (Guest, Bunce and Johnson, 2006). Our study therefore included a representative crosssection of key stakeholders, which provides some reliability for cross-checking between the literature and the parties within the relationships stated in the framework.

Semi-structured interviews were used, allowing a high degree of flexibility for respondents to convey their perspectives more widely on issues they felt relevant to the topic discussed (Haddock-Fraser and Hampton, 2012). A core list of questions (the interview protocol: See Appendix) was utilised but respondents also had the space and freedom to raise other issues and any concerns. Furthermore, the semi-structured format mean that respondents could be asked to elaborate or explain their reasoning behind their replies whenever necessary. Questions were asked concerning the relationship between cluster actors, perceptions of TNCs' involvement in Bali and concerning the complexity of government structures. Interviews were designed to allow a more nuanced understanding of the network within cluster actors and potential barriers to competitiveness. Data were coded and then analysed using Nvivo software to examine key themes based on testing the framework's components. An interpretivist philosophy was adopted due to the diverse need to understand different stakeholders' views to check on the determinants of Kim and Wicks' framework. This is a good fit with the identification of different stakeholder's views on destination competitiveness, since by understanding the subjective meanings stimulating or inducing the behaviour of the social actors, more could be learnt not just about different stakeholders' concerns and opposing views, but also the reasoning behind their perceptions and actions. Since the research objective was to gain deeper insight into key stakeholders' relationships, adopting such an approach was the most appropriate methodology. With the complex relationship between cluster actors and barriers preventing effective networking, it was necessary to understand more comprehensively the network especially in a 
small, developing destination like Bali. Applying Kim and Wicks' framework enabled a richer, more textured understanding of the complex, bureaucratic government system; how cluster actors collaborate, and the diverse local social phenomena and perspectives, whilst at the same time testing this theory in a specific, small tourist island context.

\section{Results and Analysis}

\subsection{Four factors of Tourism Cluster}

The complexity of numerous stakeholders involved in the fragmented tourism industry was investigated. As noted earlier, most previous destination competitiveness models incorporated or reformulated Porter's (1990) four factors as fundamental elements in destination competitiveness. Our findings do not make an exception supporting all factors ranging from core resources; demand conditions; complementary conditions and destination management as important features for destination competitiveness in Bali (See Appendix: Table 4 for more direct quotations from respondents). Interviews supported the significance of Porter's four conditions as important features in creating a memorable experience of a destination, thus achieving competitive advantage. Our results show all factor conditions in Kim and Wicks' framework are proven to be useful in enhancing destination competitiveness in a small mature destination.

\subsection{Cluster Actors}

Since tourism is a fragmented industry (Hall, 2005), a number of different but complementary service providers are involved ranging from small-scale local businesses like vendors along Kuta beach; SMEs such as tailoring, tattoo shops and massage parlours; through to large TNCs which 
vary from luxury hotels to international tour operators. Interview respondents all agreed about the significance of geographical proximity of complementary firms which will later generate positive externalities as claimed by Marshall (1920) and Porter (1998). Stakeholders like the Bali Tourism Board (BTB) and NGOs claimed that, "tourism areas should always be made up of complementary firms situated next to each other for the convenience of tourists" (Respondent 5). This is significant because it is the idea of offering the whole package within close proximity. Shopping malls, restaurants, hotels, transportation and attractions - if located together - create the sense of convenience for tourists leading to more effective satisfaction of their needs, maximizes profits, and facilitates teamwork. Results also supported the notion of clusters leading to enhanced teamwork and positive synergy by situating complementary businesses together. Respondent 19 commented: "Tourism is not a one person game. Businesses could profit by sharing costs for promotions for instance and the whole process of what tourists experience from the airport, to accommodation, food and many others need collaboration to ensure a comfortable and unforgettable stay". All respondents agreed with the basic notion of cluster theory and concurred that this affects Bali's competitive position as a destination.

\subsubsection{The arrival of TNCs}

Another finding was the inclusion of tourism TNCs as a cluster actor (as expected in Kim and Wicks' model). There were mixed opinions between respondents from different parts of Bali about the arrival of TNCs. Some respondents in Legian and Kintamani had particularly strong negative feelings towards the TNCs' arrival. The main reason given concerned the perceived unequal benefits distributed across the island. These respondents could be generally categorised as people who receive less benefit from tourism. The lack of resources available to compete from 
poorer locals ${ }^{1}$ and the lack of awareness towards villagers by the authorities, all helped create a pessimistic view of TNCs by some locals.

Furthermore when questioned about competing with TNCs, villagers complained "it is even hard for us to compete with people from Jakarta businesses, let alone international chains. Their productions of coffee are from factory. . . It is made even harder to compete with them as they have reputations and brands" (Respondent 15). Other respondents who experienced less benefit from tourism supported this argument and agreed that foreigners were normally equipped with sufficient capital, skills and management to run their business properly while locals have less management skills or capital for start-ups. A pattern could be discerned where Balinese businesses appeared normally to be SMEs owned by local entrepreneurs, with larger companies being owned by foreigners or Jakarta conglomerates. This reinforces findings from other studies (Hitchcock and Darma Putra, 2007; Bunnell et al, 2012).

The rest of the majority of the other respondents from Kuta, Ubud and Denpasar expressed both positive and negative views on the TNCs. Most respondents were people directly involved in tourism businesses, the Bali Tourist Board (BTB) or academics and they commonly expressed gratitude for the improved infrastructure associated with TNCs which then attracts more investors to Bali; but at the same time they expressed concerns about issues such as overcrowding and the TNCs' political influence over Bali's tourism. Respondent 3 said: “If you walk out of Kuta Street and you can see countless international chains from restaurants to cafes and shops. They are all owned by foreigners...The local stalls are the minority which is [sic] situated probably at the edge of the street catering for locals only, while most tourists spend on restaurants owned by foreigners." Academic respondents expressed concerns over increasing FDI and the high reliance on international capital for tourism investment. Results showed the 
significant role of TNCs in developing economies as asserted in Kim and Wicks' framework. Half of the respondents, mostly vendors, local shop owners, freelance drivers etc expressed difficulty in competing with TNCs or Jakarta conglomerates due to their high capital and growing presence in Bali.

On the other hand, some respondents expressed more optimistic views that they should not compete with TNCs as they are selling a different product. These were respondents including academics, NGOs, BTB officers and owners of medium-sized businesses. One said: "Since we are selling different products why do we have to compete? We can sell better service, sell a smile along with our souvenirs, and give them a sense of Balinese 'feel' by friendly haggling" (Respondent 6). Another (a lecturer) argued that Balinese have their own small businesses: "Although we have to admit that most businesses owned by locals are small but locals are actually still benefiting from tourism. They are both attracting different market segments, therefore not competing directly with each other" (Respondent 20). This suggests some differences opening up with Kim and Wicks' model about the TNCs' contribution to knowledge spillover to domestic firms, which was supposed to gradually lead to increasing competition between domestic firms and the TNCs. Furthermore, our study also reveals that local businesses do not normally compete directly with TNCs. As respondents noted, local owned (Balinese) businesses and TNCs target different segments, and therefore do not compete directly. Results also showed that locals operate their businesses at a far smaller scale such as car rental, warung (food stalls) or laundries. A number of respondents expressed the initial dependence on TNCs as being necessary. For instance respondent 7 said "It is inevitable for foreign investors to invest in Bali as we need them to help Bali develop in terms of infrastructures and hotels. It might be difficult for locals to build a 5 star resort but it is not 
impossible for locals to go into business at a smaller scale in terms of hostels or local shops". Respondent 4 said "International investor is a must from the beginning as we were depending on their money to invest and make Bali a beautiful and presentable state towards outsider [sic]. We need basic infrastructure for any tourists to come, so needed money from investors". However, all respondents felt that Bali had too many foreign investors. This shows that it is the entrepreneurial response that Balinese react to a given situation that enhances their innovativeness instead of competition that stimulates new business formation which supports innovation as claimed by Porter (1998). Their opinion illustrates the way that most developing economies rely on external funds from TNCs and FDI to inject capital which assists tourism development and other related value-added activities. This illustrates the significant role of TNCs in developing economies as claimed by Kim and Wicks, but however challenges the notion that competition was the main factor that stimulates new business formation or supports innovation. Our results show that local Balinese businesses appear to have fewer chances in competing directly with TNCs, and that both are targeting different market segments. Although the initial dependence on TNCs was noted by most respondents, they also expressed concerns over foreign investors' dominance. The number and size of international resorts in Bali and the proliferation of international brands exemplify over-dependence on external capital, which might raise problems for its longer-term sustainable development.

\subsubsection{Companies}

All respondents showed clear understanding that tourism does not only depend on one single service, but relies on other service providers to offer the entire positive experience. Hence most cluster actors, especially tourism suppliers, were attempting to collaborate with other actors like 
the service providers, or even competitors, to enhance a quality product. This concurs with Cunha and Cunha (2005) that the relationship between cluster actors can be comprehended horizontally by the creation of strategic alliances, or vertically by the creation of strategic 'nets'. The two directional arrows between TNCs and companies in the Kim and Wicks' model demonstrates 'co-opetition', which, as noted earlier, is where each actor could work cooperatively with other actors while simultaneously also competing fiercely (Brandenburger and Nalebuff, 1997). Our study partially supports the theory of co-opetition as claimed by Kim and Wicks. Co-opetition did exist between TNCs and medium size companies such as tour operators, hotels or travel agencies where positive synergy was encouraged, creating benefits for the entire cluster. The majority of the resorts and hotels in the southern part of Bali were found to be collaborating with each other as well as working with complementary industries such as tour operators and transportation companies to further add value towards providing 'allinclusive' services. One common example of co-opetition can be seen by e-marketing or online booking system where recommendations of hotels and transportations services were suggested by tour operator's websites, developing an efficient, value-added internet based system. Hotels and resorts are competing with each other whilst working cooperatively as allies to accomplish their shared goals.

In comparison, respondents who were small entrepreneurs did not express the significance of co-opetition. This symbiotic relationship of competition and cooperation between TNCs and small domestic businesses does not seem to exist. Respondents expressed that small entrepreneurs like local food stalls or bed and breakfast do not usually share the same target market with TNCs, hence having no collaboration, nor competition. Results show co-opetition occurring mainly between TNCs and medium sized companies or companies at the same level 
(Hotel vs. Hotel, Resorts vs. Resorts), rather than companies at different levels (Resort vs. Hostel). Categorisation of 'companies' as cluster actors in the Tourism Cluster Development model by Kim and Wicks can be criticised as a generalisation since companies involves different kinds of businesses as well as firm size. Our results show that co-opetition occurs but not usually between TNCs and small domestic firms, instead it is between TNCs and medium to large companies at a similar level in the same sector.

\subsubsection{Government}

Results show a slight negative pattern from this attribute. Respondents expressed great dissatisfaction with the Balinese provincial government stating that plans were normally not implemented due to limited budgets or high levels of bureaucracy: "Some government officers who implement plans are not experts on the field of tourism. They might make decisions based on their own agenda and just by their ability to do so - holding higher ranks" (Respondent 10). Another said, "Government might be able to take advantage of locals as we have no or little idea and information on what is going on within the government structure and whether appropriate decisions is being made based on my best interest" (Respondent 20). Our findings showed that the existing multi-layered, bureaucratic government system is itself filled with conflicting interests hindering effective collaboration between cluster actors. With more than half of the respondents describing government incompetence, serious questions arise over the provincial government's role to encourage and provide a healthy environment for cluster actors.

Besides playing an important role in creating and implementing plans, government needs to deal with crisis management when unforeseen events occur. In Bali, this crystallised in the 2002 bombings. Respondents perceived that the Balinese government's lack of preparation and 
inability to react effectively led to bankruptcy in tourism-related businesses and 50-60\% unemployment in the industry between October 2002 and May 2003 (World Bank/UNDP, 2006). International tourist arrivals to Bali fell drastically after the bombing with arrivals from the UK and Japan falling fastest ( $48.3 \%$ and $38.4 \%$ respectively). The significance of the role of government therefore affects destination competitiveness, as by implementing practicable policies; and promoting Bali effectively, competition and visitor numbers will be enhanced, facilitating its overall competitiveness.

Most respondents who were directly involved in tourism enterprises had negative views on the relationship between the provincial government and local business. Respondents felt that the Balinese government had not provided an optimal environment for businesses to flourish. With an ineffective and bureaucratic government system (and also corruption noted by respondents), this suggests that government did not provide the strong supportive network needed for proper cluster development.

However, despite the negative comments, respondents also had supportive views of the positive relationship between the provincial government and Bali Tourism Board, as BTB is an association formed to assist government in strategic planning for policymakers. This demonstrates proper collaboration and networking. Tourism-related businesses appeared to work closely with BTB in destination promotion, as well as developing strategies for branding Bali as a destination. Nevertheless, not all types of companies worked so closely with BTB. Results showed that most big brand hotels worked more closely with BTB compared with hostels and guest houses. This seems reasonable since the promotion of Bali as 'island paradise' normally focusses on resorts and large hotels and less on budget accommodation or guest houses. Our 
findings show an overall positive relationship between companies and BTB and also that relationships expressed are mainly based on mutual benefits gained by individual cluster actors.

According to the academic respondents, there are constantly differing perspectives on Bali's development between academics and government, thus creating intense conflicts between both clusters. "Government sometimes have their own political agenda behind those developments and we as academics have the responsibility and ethics [to] inform and discuss with planners the appropriate strategy to ensure sustainable development. We will not just tell them what they want to hear! What is the point of such discussions if our opinions are not taken into account?" (Respondent 14). Results show limited or no contact between universities and other cluster actors such as companies, government and DMOs. This does not concur with Kim and Wicks' model over the significance of universities as an important attribute here. This is mainly due to the conflict of objectives and dissonance expressed by respondents. However, if a more effective network could be created between educational institutions and other related actors, this could facilitate innovation leading to increased destination competitiveness.

\section{Discussion and Conclusion}

Findings from Bali support the validity of Porter's National Diamond Model (1990) where the four conditions (core resources, demand conditions, complementary conditions and destination management) have proved to be important factors for destination competitiveness. Bali was seen to be successful, with all the four factor conditions which will be an added advantage in its global competitiveness. This paper contributes to the debate by addressing new and different attributes such as TNCs, universities, and the concept of co-opetition, as being significant attributes in Kim and Wicks' (2010) initial model. The paper also illustrates a detailed situation 
in Bali where several intricate issues and relationships can be clearly identified in this small, but mature, destination.

Relationships between cluster actors were evident in Bali by means of communication and collaboration. The highlights of collaboration between cluster actors and the difference in roles and responsibilities between Porter's four condition and cluster actors were all seen with some results agreeing or partially agreeing with the framework. The theory of co-opetition for instance, was claimed to be positive between TNCs and local companies. However, co-opetition was found to be only possible between TNCs and medium to large size businesses within the southern part of Bali. TNCs and medium sized companies such as tour operators, hotels or travel agencies were working together as suggested by Kim and Wicks, since related and supported industries tend to cooperate to maintain the quality of the experience at a destination, but at the same time also compete to survive and gain market share. Our findings, on the other hand, showed limited relationships between small local businesses and TNCs due to its dissimilar target markets. Our results partially support this notion as smaller domestic businesses did not seem to engage in such relationships. The significance of TNCs in contribution of knowledge spillover towards domestic firms; stimulating new business formation; and supporting innovation, as asserted in the framework, does not concur with our findings from the southern region of Bali. Respondents evidenced concern about TNCs' presence in Bali and would prefer government to limit such investment. We concur with the recent call from Bouncken et al., (2015) for further research on the relationships between TNCs and small firms' co-opetion. The Balinese from the Southern region seemed to embrace an entrepreneurial response in their own businesses through wishing to deal with tourists without any external interventions. 
While the results show partial agreement with the theoretical aspects of the framework, there are also areas which concur fully. The importance of cluster actors' relationships was highlighted showing an overall positive relationship between the provincial government and the Bali Tourism Board due to their similar marketing and promotion objectives. Similarly, a positive relationship between companies and DMOs was also evident due to mutual benefits gained through promoting Bali as an attractive destination. Nonetheless, limited relationships were found between universities and other stakeholders as well as between the provincial government and businesses. This is due to the existing multi-layered, bureaucratic procedures/structures hindering effective collaboration between cluster actors. Conflict of interest was also evident within governmental departments which might act as a barrier to more effective collaboration. Further, a dissonance of views were also obvious between academics and government over managing Bali as a destination (see Mossner and Gomes de Matos, 2015 on academics as 'hidden planners').

Kim and Wicks' conceptual framework indicated the significance of collaboration between cluster actors; and the difference in roles and responsibilities between Porter's four conditions, all act as useful attributes showing key potentials and limitations of Bali. The results demonstrate the need for better linkages among cluster actors to facilitate a more efficient, effective network to assist economic development and innovation in a mature destination such as Bali. This systematic analysis and comparison of key tourism elements provides a more in-depth and nuanced analysis of a destination's strengths and weaknesses and also provides deeper knowledge of a destination's competitive position which is essential within the fast-changing tourism industry. 
The paper set out to explore the determinants and attributes from Kim and Wicks' model. It provides a first attempt to apply this revealing, but highly abstract, model to a small mature destination such as Bali. This detailed model provides a clear understanding for planners, a clear and detailed analysis of the destination's internal dynamics, and points to ways forward for planning future strategies. Since Bali is a small, but mature, destination with interrelated problems, by systematically analysing where its problems and challenges lie, it is now possible begin to make a destination more competitive and allow it to compete more effectively. This should, in turn, significantly assist both the tourism industry and the host community. Government planners and destination managers in other less developed countries may be able to use lessons from here to facilitate more effective destination competitiveness. This will also enable more effective planning, more efficient use of resources, and - all things being equal result in more positive economic development benefits being retained by host community as well as the tourist industry.

\section{Acknowledgements.}

The authors are grateful to Martin Meyer and Paul Phillips for their constructive comments on earlier versions of the paper. We are also grateful to the interview respondents in Bali who gave their time freely. The usual disclaimers apply. 


\section{References.}

Aditjondro, G. 1995, Bali, Jakarta's Colony: Social and Ecological Impacts of Jakarta-based conglomerates in Bali's tourism industry. Asia Research Centre Working Paper No.58. Perth: Murdoch University.

Ashworth, G. J. (1992), Is there an urban tourism? Tourism Recreation Research, 17(2), 3-8.

Baker, K. and Coulter, A. (2007) Terrorism and Tourism: The Vulnerability of Beach Vendors' Livelihoods in Bali. Journal of Sustainable Tourism, 15 (3): 249- 266.

Berger, A.A. (2013) Bali Tourism. Routledge, London.

Bernini, C. (2009), Convention industry and destination clusters: Evidence from Italy, Tourism Management, 30(6), 878-889.

Bloomberg Business, (2015), Bali leads Indonesia effort to lure tourists with free visas [Online] Available from: http://www.bloomberg.com/news/articles/2015-06-23/bali-leads-indonesiapromotion-to-lure-tourists-with-free-visas [Accessed 28 June 2015].

Bouncken, R. Gast, J., Kraus, S. \& Bogers, M. (2015), Coopetition: a systematic review, synthesis, and future research directions. Review of Managerial Science, 9, 577-601.

BPS (2013), Social and Population: Statistics Indonesia [Online] Available from: http://dds.bps.go.id/eng/ [Accessed 18 February 2013].

Brandenburger, A. M., \& Nalebuff, B. J. (1997), Co-Opetition, 1st ed., Broadway Business, New York.

Britton, S.G. (2001), Tourism, dependency and development, In Apostolopoulos, Y., Yiannakis, A., Leivadi, S. (eds) The Sociology of Tourism: Theoretical and empirical investigations. Routledge, London. 
Brohman, J. (1996), New directions in tourism for third world development, Annals of Tourism Research, 23(1), pp. 48-70.

Bunnell, T., Muzaini, H. \& Sidaway, J. (2012) Global City Frontiers: Singapore's hinterland and the contested geographies of Bintan, Indonesia. In Wastl-Walter, D., (ed) The Ashgate Research Companion to Border Studies. Ashgate, Aldershot.

Chambers, R., (1983) Rural Development. Putting the Last First. Longman, London.

Cole, S. (2012) A Political Ecology of Water Equity and Tourism: A Case Study from Bali. Annals of Tourism Research, 39 (2), 1221- 1241.

Cohen, S.A. (2013) Reflections on reflexivity in leisure and tourism studies. Leisure Studies, 32 (3), 333-337

Cole, S. and Browne, M. (2015) Tourism and Water Inequity in Bali: A Social-Ecological Systems Analysis'. Human Ecology. Online version published 16 May. DOI: 0.1007/s10745$015-9739-\mathrm{z}$

Connell, J. (1993) Bali revisited: death, rejuvenation and the tourist cycle. Environment and Planning D, Society and Space, 11: 641-661.

Crouch, G. I., \& Ritchie, J. B. (1995), Destination competitiveness and the role of the tourism enterprise, Proceedings of the Fourth Annual Business Congress, (p 43-48), Istanbul, Turkey, July 13.

Crouch, G.I. \& Ritchie, J.R. (1999), Tourism, competitiveness, and societal prosperity, Journal of Business Research, 44(3), 137-152.

Crouch, G.I. (2011), "Destination competitiveness: An Analysis of determinant attributes", Journal of Travel Research, 50 (1), 27-45. 
Croes, R. (2011), Measuring and explaining competitiveness in the context of small island destinations, Journal of Travel Research, 50(4), 431-442.

Cunha, S.K. \& Cunha, J.C. (2005), Tourism cluster competitiveness and sustainability: proposal for a systemic model to measure the impact of tourism on local development, Brazilian Administration Review, 2(2), 47-62.

Cukier, J., \& Wall, G. (1994), Informal tourism employment: vendors in Bali, Indonesia, Tourism Management, 15(6), 464-467.

Dahles, H., \& Bras, K. (1999), Entrepreneurs in Romance Tourism in Indonesia, Annals of Tourism Research, 26(2), pp. 267-293.

Dinas Pariwisata Bali (2014) Statistics. http://www.disparda.baliprov.go.id/en/Statistics2 (Accessed 12 September 2014)

Dunning, J. H. (1993), The theory of transnational corporations, Vol. 1, Taylor \& Francis, London.

Dwyer, L., Forsyth, P., \& Rao, P. (2000), The price competitiveness of travel and tourism: a comparison of 19 destinations, Tourism Management, 21(1), pp 9-22.

Dwyer, L. \& Kim, C. (2003), Destination competitiveness: determinants and indicators, Current Issues in Tourism, 6(5), 369-414.

Ellis, S. \& Sheridan, L. (2014) A Critical Reflection on the Role of Stakeholders in Sustainable Tourism Development in Least-Developed Countries. Tourism Planning and Development.

Online version published 7 March. DOI: 10.1080/21568316.2014.894558

Enright, M.J. \& Newton, J. (2004), Tourism destination competitiveness: a quantitative approach, Tourism Management, 25(6), 777-788. 
Faugier, J. \& Sargeant, M. (1997) Sampling hard to reach populations. Journal of Advanced Nursing, 26(4), 790-797.

Enright, M.J. \& Newton, J. (2005), Determinants of tourism destination competitiveness in Asia Pacific: Comprehensiveness and universality, Journal of Travel Research, 43(4), 339-350.

Go, F. M., \& Govers, R. (1999), The Asian perspective: which international conference destinations in Asia are the most competitive? Journal of Convention \& Exhibition Management, $1(4), 37-50$

Go, F. M., \& Govers, R. (2000), Integrated quality management for tourist destinations: a European perspective on achieving competitiveness, Tourism Management, 21(1), 79-88.

Go, F., and A. Williams (1993), Competing and Cooperating in the Changing Tourism Channel System, Journal of Travel and Tourism Marketing, 2, 229-248.

Guest, G., Bunce, A. \& Johnson, L. (2006), How many interviews are enough? An experiment with data saturation and variability, Field Methods, 18 (1), 59-82.

The Guardian (2012), Beauty of Bali under threat from pressures of Mass Tourism, [Online] Available from: http://www.theguardian.com/world/2012/aug/07/bali-tourism-threatens-naturalbeauty (Accessed 28 June 2015)

Hall, C. M. (2005), Tourism: Rethinking the social science of mobility, Prentice Hall, London. Hall, C. M., \& Thomas, R. (2004), Small firms and wine and food tourism in New Zealand, In Issues of collaboration, clusters and lifestyles. In Thomas, R. ed, Small firms in Tourism, International Perspectives, pp 167-181. Elsevier, Oxford.

Hassan, S.S. (2000), Determinants of market competitiveness in an environmentally sustainable tourism industry, Journal of Travel Research, 38(3), 239-245. 
Haddock-Fraser, J. and Hampton, M.P. (2012) Multi-stakeholder values on the sustainability of dive tourism: case studies of Sipadan and Perhentian islands, Malaysia. Tourism Analysis, 17 (1) 27-41.

Hampton, M.P. (2010) Enclaves and ethnic ties: local impacts of Singaporean cross-border tourism in Malaysia and Indonesia. Singapore Journal of Tropical Geography, 31(2) 239-253. Heath, E. (2003), Towards a Model to Enhance Destination Competitiveness: A Southern African Perspective. Journal of Hospitality and Tourism Management, 10(2), pp. 124-141. Henderson, J. C. (2003), Terrorism and tourism: Managing the consequences of the Bali bombings. Journal of Travel and Tourism Marketing, 15(1), 41-58.

Hitchcock, M. (2000), Ethnicity and tourism entrepreneurship in Java and Bali, Current Issues in Tourism, 3(3), pp. 204-225.

Hitchcock, M. (2001), Tourism and total crisis in Indonesia: the case of Bali, Asia Pacific Business Review, 8(2), pp. 101-120.

Hitchcock, M., King, V., \& Parnwell, M. (2009), Current Issues in South-East Asian Tourism, In: Hitchcock, M., King, V., \& Parnwell, M. (eds) Tourism in South-East Asia: Challenges and New Directions, pp 309; NIAS Press, Copenhagen.

Hitchcock, M. \& Putra, I.N.D. (2005), The Bali bombings: Tourism crisis management and conflict avoidance, Current Issues in Tourism, 8(1), 62-76.

Hudson, S., Ritchie, B. and Timur, S. (2004), Measuring Destination Competitiveness: an empirical study of Canadian Ski resorts, Tourism and Hospitality Planning and Development, 1(1), 79-94.

Hussey, A. (1989), Tourism in a Balinese village, Geographical Review, 79(3), 311-325. 
Jackson, J., and P. Murphy (2002), Tourism Destinations as Clusters: Analytical Experiences from the New World, Tourism and Hospitality Research, 4(1), 36-52.

Jackson, J. \& Murphy, P. (2006), Clusters in regional tourism An Australian case, Annals of Tourism Research, 33(4), 1018-1035.

The Jakarta Post (2013), Bali ready to host APEC, [Online] Available from:

http://www.thejakartapost.com/news/2013/09/11/bali-ready-host-apec.html (Accessed 1 July 2015)

Kalisch, A. (2001) Tourism as Fair Trade: NGO Perspectives. Tourism Concern, London.

Kim, N. \& Wicks, B.E. (2010), Rethinking Tourism Cluster Development Models for Global Competitiveness, International CHRIE Conference-Refereed Track. July 30, University of Massachusetts.

Kusluvan, S. \& Karamustafa, K. (2001), Multinational hotel development in developing countries: an exploratory analysis of critical policy issues, International Journal of Tourism Research, 3(3), 179-197.

Lewis, J. and Lewis, B. (2009) Bali's Silent Crisis. Desire, Tragedy and Transition. Lexington Books, Lanham, Maryland.

Marshall, A. (1920), Principles of Economics: An Introductory Volume. Macmillan, London. Michael, E. J. (2003), Tourism micro-clusters, Tourism Economics, 9(2), 133-145.

Minca, C. (2000) 'The Bali Syndrome': the explosion and implosion of 'exotic' tourist spaces. Tourism Geographies 2 (4), 389-403.

Moric, I. (2013) Clusters as a factor of rural tourism competitiveness: Montenegro experiences. Business Systems Research, 4(2), 94-107. 
Mossner, S. and Gomes de Matos, C. (2015), The hidden planners? Academic knowledge production and urban planning. Paper presented at the RC21 International Conference "The Ideal City: between myth and reality. Representations, policies, contradictions and challenges for tomorrow's urban life" Urbino, Italy 27-29 August

Nadvi, K. (1999). Collective Efficiency and Collective Failure: The Response of the Sialkot Surgical Instrument Cluster to Global Quality Pressures, World Development, 27(9), 1605-1626. Newall J.E, (1992), The Challenge of Competitiveness, Business Quarterly, 56(4), 94-100. Pagdin, C., (1989) 'Assessing Tourism Impacts in the Third World: a Nepal Case Study.' Progress in Planning, 44, (3) 185-226.

Pearce, D.G. (1997), Competitive destination analysis in Southeast Asia, Journal of Travel Research, 35(4), 16-24.

Pearce, D.G. (2014) Towards an Integrative Conceptual Framework of Destinations. Journal of Travel Research, 53(2), 141-153.

Picard, M. (1996) Cultural tourism and touristic culture. Archipelago Press, Singapore. (translated by D. Darling).

Picard, M. (2009) From 'Kebalian' to 'Ajeg Bali': Tourism and Balinese Identity in the aftermath of the Bali bombing. In Hitchcock, M., King, V.T. and Parnwell, M. (eds) Tourism in South-East Asia: Challenges and New Directions. NIAS Press, Copenhagen.

Porter, M.E (1990), The competitive advantage of nations. Harvard Business Review, 68(2), 7393.

Porter, M.E. (1998), Competitive strategy: techniques for analyzing industries and competitors. Free Press, New York. 
Putra, I. \& Hitchcock, M. (2006), The Bali bombs and the tourism development cycle, Progress in Development Studies, 6(2), 157.

Ramstedt, M. (2012) Process of Disembedding and Displacement: anomie and the juridification of religio-ethnic identity in post-New Order Bali. Asian Ethnicity, 13 (4): 323-339.

Ritchie, J. R. B., \& Crouch, G. I. (2000). The Competitive Destination: A Sustainability

Perspective, Tourism Management, 21(1), 1-7.

Schmitz, H. (1999). Global Competition and Local Co: Success and Failure in the Sinos Valley, Brazil, World Development, 27(9), 1627-1650.

Schmitz, H. \& Nadvi, K. (1999), Clustering and Industrialization: Introduction, World Development, 27(9), 1503-1514.

Shaw, B.J. \& Shaw, G. (1999), ‘Sun, Sand and Sales’: Enclave Tourism and Local Entrepreneurship in Indonesia, Current Issues in Tourism, 2(1), 68-81.

Suasta, P., \& Connor, L. (1999). Democratic mobilization and political authoritarianism:

Tourism developments on Bali. In R. Rubinstein \& L. Connor (Eds.), Staying local in the global village: Bali in the twentieth century (pp. 91-122). Honolulu: University of Hawaii Press.

Sumaco, F.T. \& Richardson, S. (2011), An Analysis on International Tourists' Perceptions towards Destination Branding:"Visit Indonesia 2008” Marketing Campaign, The $2^{\text {nd }}$ International Research Symposium in Service Management, Yogyakarta, Indonesia. UNCTAD (2007) FDI in Tourism: the Development Dimension. UN Conference on Trade and Development. UN Publications, Geneva.

UN WTO (2012). Challenges and Opportunities for Tourism Development in Small Island Developing States. UN World Tourism Organization, Madrid.

UN WTO (2014). World Tourism Highlights 2014. UN World Tourism Organization. Madrid. 
Wall, G. and Long, V. (1996) Balinese Homestays: an indigenous response to tourism opportunities. In Butler, R. and Hinch, T. (eds) Tourism and Indigenous Peoples. ITP, London. Wall, G. (1998) Landscape Resources, Tourism and Landscape Change in Bali, Indonesia. In Ringer, G. (ed) Destinations: Cultural Landscapes of Tourism. Routledge, London. pp 51- 62. World Bank/UNDP (2006) Bali: Beyond the Tragedy, World Bank, Washington DC. 


\section{Appendices}

\section{Interview Questions for Bali}

\section{$\underline{\text { Interview } 1}$}

\section{Balinese/Locals/Villagers}

1. Polite conversation to let respondents feel at ease.... How long have you been in this job? Do you like it? What are your responsibilities? Maybe get him/her to speak up on his/her background and experience.

2. Some people feel that government (Central and provincial) are exploiting/ taking advantage of tourism. What do you think?

3. Do locals feel that the tourism industry is dominated by foreign owners? Do you feel that it is difficult to compete with international chains or not?

4. Do you think the government should limit the number of Multinational Corporations in Bali? [Is Bali highly dependent on external investment?] Why so? [To check on the importance of MNCs in developing countries -Porter emphasized]

5. Without the investment of Multinational Companies, would you think Bali will be successful? If not, why not? What would make a difference?

6. Do you feel part of/involved in the decision making process (in terms of votes and participation) when it comes to tourism development? [Community participation as emphasis in cluster theory]

7. What do you think are the difference between tourists staying in a 5 star hotels and those staying in local bed and breakfast/ accommodation?

8. Do you think that money earned by Bali tourism is being reinvested back to Bali? Why so? [To check on their opinion on whether most of the profits earned by tourism are sent to bigger regions like Jakarta and the rest of Indonesia]

9. What do you think are the reasons for Bali being such a successful destination?

10. From your point of view, do you think domestic customer needs and local resources plays an important role in contributing towards Bali being such a popular destination? 


\section{Interview Questions for Bali}

\section{Hoteliers/Balinese Entrepreneurs/ People who offer tours/ Taxi drivers*}

*[If respondents fall in to the above category, the following questions below will be asked]

11. Are your business/this hotel liaising with any other company or government board/ DMO? Or competing against each other? [To test the effectiveness/partnership on cluster actors]

12. Do you think tourism related companies are working closely with the government/ tourism board? What do you think about their relationship? [to check on the interconnection between clusters that Porter's stresses] Are there any examples you know of?

13. Are you liaising/ in contact with other establishments like local souvenir shops/ taxi companies or local hawker stalls/ Bed and breakfast/ local hostels to work cooperatively? If no, why not? If yes, what benefits does it brings? [To check on the concept of co-opetition]

14. Are there a lot of rules and regulations (difficult procedures) that one has to go through in order to open/manage their own business? Culture could be one factor affecting competitiveness. [Test for government and Porter's fourth feature 'firm strategy, structure and rivalry']

15. Do you often listen to customers' recommendation or pay attention to what they prefer trying to satisfy their needs? [react to customer needs in order to stay competitive] 


\section{Interview Questions for Bali}

\section{Interview 2}

\section{NGO's/ Academics/People with tourism knowledge and experience/ BTB}

[If Academics, NGOs and respondents working in BTB are Balinese, Q1-15 will also be asked in addition to the ones below]

1. Do you think that tourism related companies work together with other institutions such as Universities or non-profit organisations? [To check if the Universities/DMOs/ NGOS are part of the tourism clusters] How would you describe their relationship?

2. Bali has had a large number of PR campaigns promoting domestic or international tourism? In your opinion, does it help improve tourism?

3. Do you think that profits gained from tourism are being reinvested in Bali? From your point of view in which sector of tourism do you think money is most likely to stay within the community?

4. What is your opinion on "Tourism improving the quality of life of Balinese"? And how can this be seen, if at all?

5. What do you think of the provincial government aiming 'tourism as the main development tool for Bali'?

6. Do firms 'Cooperate' or 'Compete' or both, with each other in this lucrative industry? From your point of view should firms cooperate or compete in order to stay competitive?

7. Would you agree that the proximity (located close together) of firms especially complementary firms brings benefit (create a better network and generate positive externalities) between companies and institutions? [To test the concept of diagonal clustering] If yes, what benefits do you think it will bring? If no [if cluster theory is applied] do you think it will be beneficial?

8. What do you think of the concept of firms collaborating/located closely in the tourism context? What benefits would you think firms could gain? 
9. Are they any partnership between government and private companies in the tourism industry i.e. joint marketing/ promotion? From your point of view, do you think that this kind of partnership is useful/successful? Are there any examples you know of?

10. As Bali gradually became such a competitive destination, how do you think this has affected the lives of the locals? If so, in what main ways?

11. What do you think are the reasons for Bali being such a successful destination?

12. Some countries might own the same type of resources Bali had. Why do you think Bali turns out to be more successful than others? [Beaches, scenery, culture, food, skilled labour, history infrastructure etc- test on factor conditions of Porter's model]

13. Do you think that home demand conditions such as domestic customer needs/growth rate affects the rate of innovation of tourism? Do they play an important role in preparing industry or a country to build advantages globally?

14. Does the provincial government foster policies such as destination quality management, safety and environment regulations to ensure high quality tourism services in Bali?

15. Tourism can be seen as one of the most successful industry in Bali, do you think it actually has increased the quality of life of citizens?

16. Are there any votes taken/participation from locals from any tourism related projects? [Community participation as emphasis in cluster theory]

17. Are there any jointly owned (locals and foreigners) tourism businesses? 


\begin{tabular}{|c|c|c|c|c|c|c|c|}
\hline Name & Age & Sex & Town/Country & Nationality & Occupation & $\begin{array}{l}\text { No. of Years } \\
\text { in Business }\end{array}$ & Interview Duration \\
\hline R1 & $30-40$ & Male & Kuta & Balinese & Freelance taxi driver & 17 & $1 \mathrm{Hr} 32$ Minutes \\
\hline $\mathrm{R} 2$ & $35-40$ & Male & Kuta & Balinese & Travel agency in Barong & 20 & 47 Minutes \\
\hline R3 & $40-50$ & Male & Kuta & Balinese & Triad leader & 15 & 58 Minutes \\
\hline R4 & $30-40$ & Male & Kuta & Balinese & $\begin{array}{l}\text { Henna business/ professional } \\
\text { surfer }\end{array}$ & 7 & 48 Minutes \\
\hline R5 & $50-60$ & Male & Ubud & Balinese & $\begin{array}{l}\text { Former Secretary Bali Tourism } \\
\text { Board }\end{array}$ & 30 & $2 \mathrm{Hrs}$ \\
\hline R6 & $30-40$ & Male & Ubud & Balinese & $\begin{array}{l}\text { Coordinator in Bali Tourism } \\
\text { Board }\end{array}$ & 2 & 48 Minutes \\
\hline R7 & $30-40$ & Female & Ubud & Balinese & Driver & 4 & 1 Hour \\
\hline R8 & $50-60$ & Male & Ubud & Balinese & Tour Operator & 7 & $1 \mathrm{Hr} 41$ Minutes \\
\hline R9 & $25-30$ & Female & Ubud & Balinese & International development NGO & 3 & $1 \mathrm{Hr} 39$ Minutes \\
\hline R10 & $30-40$ & Female & Legian & Balinese & Lecturer & 6 & 44 Minutes \\
\hline R11 & $50-60$ & Male & Legian & Balinese & Carvings business & 8 & 57 Minutes \\
\hline R12 & $40-50$ & Female & Legian & Balinese & Seamstress & 9 & 52 Minutes \\
\hline R13 & $50-60$ & Male & Legian & Balinese & Bali Tourism Board & 15 & $1 \mathrm{Hr} 33$ Minutes \\
\hline R14 & $50-60$ & Male & Legian & Balinese & $\begin{array}{l}\text { Head of Master Program in } \\
\text { University }\end{array}$ & 17 & $1 \mathrm{Hr} 55$ Minutes \\
\hline R15 & $40-50$ & Male & Kintamani & Balinese & $\begin{array}{l}\text { Coffee Plantation (worked in } \\
\text { Sanur before) }\end{array}$ & 27 & $1 \mathrm{Hr} 35$ Minutes \\
\hline R16 & $40-50$ & Male & Kintamani & Balinese & Coffee plantation & 30 & $1 \mathrm{Hr} 11$ Minutes \\
\hline R17 & $30-40$ & Male & Denpasar & Balinese & Work in Temple & 2 & 20 Minutes \\
\hline R18 & $25-30$ & Female & Denpasar & Balinese & Work in Temple & 3 & 35 Minutes \\
\hline R19 & $30-40$ & Female & Denpasar & Balinese & Lecturer & 8 & 2 Hrs 20 Minutes \\
\hline $\mathrm{R} 20$ & $25-30$ & Female & Denpasar & Balinese & Lecturer & 3 & $1 \mathrm{Hr} 10$ Minutes \\
\hline $\mathrm{R} 21$ & $30-40$ & Couples & Singapore & Singaporean & Tourist & $\mathrm{N} / \mathrm{A}$ & 30 Minutes \\
\hline $\mathrm{R} 22$ & $25-30$ & Couples & California & USA & Tourist & $\mathrm{N} / \mathrm{A}$ & 25 Minutes \\
\hline R23 & $50-60$ & Male & - & Swiss & International development NGO & 2 & 1 Hour \\
\hline
\end{tabular}

Table 1: List of respondents from Bali $(\mathrm{N}=23)$. 


\begin{tabular}{|c|c|c|c|c|c|c|c|c|c|c|c|}
\hline \multirow[t]{2}{*}{ Respondents } & \multicolumn{4}{|c|}{$\begin{array}{c}\text { People involved } \underline{D I R E C T L Y} \text { with tourism } \\
\text { businesses }\end{array}$} & \multicolumn{3}{|c|}{$\begin{array}{l}\text { People who are } N O T \text { directly } \\
\text { involved in tourism }\end{array}$} & \multicolumn{3}{|c|}{ NGOs/Academics } & \multirow{2}{*}{$\begin{array}{c}\text { People } \\
\text { with } \\
\text { limited } \\
\text { benefit } \\
\text { Villagers }\end{array}$} \\
\hline & $\begin{array}{c}\text { Taxi } \\
\text { Drivers }\end{array}$ & $\begin{array}{c}\text { Tour } \\
\text { Operator/Hotelier }\end{array}$ & Vendor & $\begin{array}{l}\text { Triad } \\
\text { Leader }\end{array}$ & Seamstress & Temple & $\begin{array}{l}\text { Carving } \\
\text { business }\end{array}$ & Lecturers & $\begin{array}{c}\text { International } \\
\text { development } \\
\text { NGO } \\
\end{array}$ & $\begin{array}{c}\text { Bali } \\
\text { Tourism } \\
\text { Board } \\
\end{array}$ & \\
\hline \multicolumn{12}{|c|}{ KUTA } \\
\hline R1 & $x$ & & & & & & & & & & \\
\hline $\mathrm{R} 2$ & & $x$ & & & & & & & & & \\
\hline R3 & & & & $x$ & & & & & & & \\
\hline R4 & & & $x$ & & & & & & & & \\
\hline \multicolumn{12}{|c|}{ UBUD } \\
\hline R5 & & & & & & & & $X$ & & $X$ & \\
\hline R6 & & & & & & & & & & $x$ & \\
\hline R7 & $x$ & & & & & & & & & & \\
\hline R8 & & $x$ & & & & & & & & & \\
\hline R9 & & & & & & & & & $x$ & & \\
\hline \multicolumn{12}{|c|}{ LEGIAN } \\
\hline R10 & & & & & & & & $x$ & & & \\
\hline R11 & & & & & & & $\mathrm{X}$ & & & & \\
\hline $\mathrm{R} 12$ & & & & & $x$ & & & & & & \\
\hline R13 & & & & & & & & & & $x$ & \\
\hline R14 & & & & & & & & $X$ & & & \\
\hline \multicolumn{12}{|c|}{ KINTAMANI } \\
\hline R15 & & & & & & & & & & & $x$ \\
\hline R16 & & & & & & & & & & & $x$ \\
\hline \multicolumn{12}{|c|}{ DENPASAR } \\
\hline R17 & & & & & & $x$ & & & & & \\
\hline R18 & & & & & & $x$ & & & & & \\
\hline R19 & & & & & & & & $x$ & & & \\
\hline $\mathrm{R} 20$ & & & & & & & & $x$ & & & \\
\hline \multirow[t]{2}{*}{ R23 } & & & & & & & & & $\mathrm{X}$ & & \\
\hline & \multicolumn{4}{|c|}{$\mathrm{N}=6$} & \multicolumn{3}{|c|}{$\mathrm{N}=4$} & \multicolumn{3}{|c|}{$\mathrm{N}=9$} & $\mathrm{~N}=2$ \\
\hline & & & erefor & tal res & ondents (21) & 2 touris & $\mathrm{N}=23$ & & & & \\
\hline
\end{tabular}

Table 2: Breakdown of the typology of stakeholder groups 
Table 3: Cross Reference of Interview Questions and Framework

\begin{tabular}{|l|l|l|}
\hline $\begin{array}{l}\text { Kim and Wicks' } \\
\text { Framework }\end{array}$ & \multicolumn{2}{|c|}{ Interview Questions Number ${ }^{1}$} \\
\hline & $\begin{array}{l}\text { Views }{ }^{2} \text { from Locals and } \\
\text { Entrepreneurs (Questions from } \\
\text { Interview 1) }\end{array}$ & $\begin{array}{l}\text { Views from academics/ } \\
\text { Bali Tourism Board/ } \\
\text { NGOs (Questions from } \\
\text { Interview 2) }\end{array}$ \\
\hline
\end{tabular}

1) Porter's Diamond Conditions:

\begin{tabular}{|l|c|c|}
\hline a) Core resources & 9 & 11,12 \\
\hline b) Demand conditions & 10,15 & 13 \\
\hline $\begin{array}{l}\text { c) Complementary } \\
\text { conditions }\end{array}$ & 9 & 8 \\
\hline $\begin{array}{l}\text { d) Destination } \\
\text { Management }\end{array}$ & 14 & 2 \\
\hline
\end{tabular}

2) Cluster Actors:

\begin{tabular}{|l|c|c|}
\hline a) Government & $2,6,8,12,14$ & $5,9^{3}, 16,17$ \\
\hline $\begin{array}{l}\text { b) Transnational } \\
\text { Corporations and FDI }\end{array}$ & $3,4,5$ & \\
\hline c) Private Companies & $7,11,13$ & 9,17 \\
\hline $\begin{array}{l}\text { d) Destination } \\
\text { Management Organisation }\end{array}$ & 11 & 13,14 \\
\hline e) University & 11,12 & $1,7,9$ \\
\hline $\begin{array}{l}\text { 3) Interrelationship } \\
\text { between cluster actors }\end{array}$ & 13 & 6,8 \\
\hline Co-opetition & & \\
\hline
\end{tabular}

\footnotetext{
${ }^{1}$ See Appendices for full Interview Questions

${ }^{2}$ Different interview questions were asked between locals, local small business (Interview 1); and academics, Bali Tourism Board and NGOs (Interview 2 as shown in appendix section). People who were involved in the tourism related management were asked more in-depth questions regarding the network between cluster actors. ${ }^{3}$ Occasionally, the same question can be categorise into few subsections. For instance, Question 9 from Interview 2: Are they any partnership between government and private companies in the tourism industry? This can be categorise under 'Interrelationship between Cluster actors', 'Government' and 'Private companies'.
} 
Table 4: Additional Direct quotations from Respondents relating to Kim and Wicks' themes

\begin{tabular}{|c|c|}
\hline $\begin{array}{l}\text { Kim and Wicks' } \\
\text { Framework }\end{array}$ & Examples of quotes relating to themes \\
\hline $\begin{array}{l}\text { Porter's four factor } \\
\text { conditions: } \\
\text { Core resources }\end{array}$ & $\begin{array}{l}\text { "You need to have something that interest people. Without the } \\
\text { resources what are we going to offer for the tourists in the first place? } \\
\text { The presence of beautiful scenery and mountains in Bali helps a lot" } \\
\text { (Respondent 15). } \\
\text { "The re-enactment of Bali dances and history and the involvement of } \\
\text { tourists in activities like wearing sarong [length of fabric, often wrapped } \\
\text { around the waist and worn by men and women] and learning the } \\
\text { Balinese lifestyle are highlights of most tourists as shown from their } \\
\text { customer feedback." (Respondent 2) } \\
\text { Comment: These findings concurs with Crouch's (2011) that core } \\
\text { resources which comprise of sub components like climate, culture and } \\
\text { the development of a broad mix of recreation and tourism activities } \\
\text { were ranked as the most important factors among the four conditions. }\end{array}$ \\
\hline Demand Conditions & $\begin{array}{l}\text { "This has been done by many Balinese vendors as well as hoteliers } \\
\text { who take into account the needs of domestic tourists needs by serving } \\
\text { 'Halal' (Islamic) cuisines" (Respondent 8). } \\
\text { Respondent } 9 \text { said "If you can't satisfy your own people, how are you } \\
\text { going to satisfy international visitors?" } \\
\text { Comment: As claimed by Dwyer and Kim (2003 p.398), "foreign } \\
\text { demand thrives more readily when domestic tourism is well } \\
\text { established". }\end{array}$ \\
\hline $\begin{array}{l}\text { Complementary } \\
\text { Conditions }\end{array}$ & $\begin{array}{l}\text { Respondent } 17 \text { said, "Who would want to come to a place where they } \\
\text { have no sanitation facilities, lack of clean water or no proper } \\
\text { accommodation? These are just basic needs if you want to attract } \\
\text { tourists." } \\
\text { The ease of flying into Bali, the ease of getting around as well as } \\
\text { minimal immigration restrictions on travelling to Bali has definitely an } \\
\text { added advantage for Bali as a destination (Respondents } 21,22 \text { ) }\end{array}$ \\
\hline Destination Management & $\begin{array}{l}\text { "Although there is an increase in middle class society with the capacity } \\
\text { to travel for leisure, there is also a large number of countries opening }\end{array}$ \\
\hline
\end{tabular}




\begin{tabular}{|c|c|}
\hline & $\begin{array}{l}\text { up to tourism especially around Asia; so marketing is the key" } \\
\text { (Respondent 23). } \\
\text { "Branding is a very significant process so other people know what Bali } \\
\text { is selling and what its Unique Selling Points are. We need to constantly } \\
\text { remind tourists how great Bali is" (Respondent 10). } \\
\text { Comment: The constant changes from branding and rebranding } \\
\text { throughout the years from 'Indonesia, Just a Smile' in } 2001 \text { to } \\
\text { 'Indonesia Endless Beauty of Diversity' in } 2003 \text { to the sudden change to } \\
\text { 'Indonesia the Colour of Life' in the same year created confusion and } \\
\text { difficulty for tourists to grasp what product Indonesia is selling } \\
\text { (Sumaco and Richardson, 2011). Indonesia is struggling to market its } \\
\text { heterogeneous ethnicity obtained in the country (Ashworth, 1992) }\end{array}$ \\
\hline \multirow[t]{3}{*}{$\begin{array}{l}\text { Cluster Actors: } \\
\text { Arrival of } \\
\text { TNCs/Destination } \\
\text { Management/ }\end{array}$} & $\begin{array}{l}\text { "We are trying our best to invent and create new strategies to } \\
\text { promote or increase our quality of services to attract more tourists } \\
\text { but they (Respondent referring to TNCs) obviously have more capital } \\
\text { and expert management staff that we can't compete with" } \\
\text { (Respondent 10). } \\
\text { Bali's promotional campaign and pricing strategies, the careful } \\
\text { planning of product development implemented by both the central } \\
\text { and provincial governments generate the highest income possible for } \\
\text { TNCs (Respondents 3,4,10 and 11). } \\
\text { Comment: This is supported by writers such as Dunning (1993), Kusluvan } \\
\text { and Karamustafa (2001) and Britton (1996) on the limited benefit of TNCs } \\
\text { for host populations. }\end{array}$ \\
\hline & $\begin{array}{l}\text { "Not only should government limit those international chains but also } \\
\text { those big companies owned by those rich people from Jakarta. They } \\
\text { tend to take most of our businesses away and leave us with nothing. I } \\
\text { know this sounds ungrateful as Bali can never be so developed } \\
\text { without them, but this does not benefit us in any way. I feel proud of } \\
\text { Bali but at the same time I feel that businesses opportunities should } \\
\text { be more widely spread" (Respondent 12). }\end{array}$ \\
\hline & $\begin{array}{l}\text { "Their production of coffee are from factory and produces more than } \\
1000 \text { packs a day while we can only produce } 30 \text { packs each day. It is }\end{array}$ \\
\hline
\end{tabular}




\begin{tabular}{|c|c|}
\hline $\begin{array}{l}\text { Interrelationship } \\
\text { between cluster actors }\end{array}$ & $\begin{array}{l}\text { made even harder to compete with them as they have reputations } \\
\text { and brands that are already famous and tourists tend to buy from } \\
\text { reliable companies with products all over Bali. What they do not know } \\
\text { is the taste of the coffee is different when produced in an authentic } \\
\text { way." (Respondent 15) } \\
\text { "It is inevitable for foreign investors to invest in Bali as we need them } \\
\text { to help Bali develop in terms of infrastructures and hotels." He added } \\
\text { "It might be difficult for locals to build a } 5 \text { star resort but it is not } \\
\text { impossible for them to go into business on a smaller scale in terms of } \\
\text { hostels, villas or local shops" (Respondent 7). } \\
\text { "Those big companies were an imperative from the beginning as we } \\
\text { were depending on their money to invest and make Bali a beautiful } \\
\text { and presentable state towards outsider. We need basic infrastructure } \\
\text { for any tourists to come, hence needed money from investors" } \\
\text { (Respondent 4) }\end{array}$ \\
\hline Companies/ FDI & $\begin{array}{l}\text { Respondents 1, 2, } 7 \text { and } 8 \text { who own businesses, expressed that they } \\
\text { normally work with other local domestic firms to enhance more } \\
\text { participation from the local community in terms of using local food } \\
\text { from farmers and laundrette services from other locals. } \\
\text { "Competition is good in a way to improve effectiveness and } \\
\text { cooperation is also necessary to give a wholesome package to the } \\
\text { tourists." (Respondent 5) } \\
\text { "Not all local guesthouses are able to compete or cooperate with } \\
\text { international hotels even as they are in the same } \\
\text { industry".(Respondent 19) } \\
\text { "We should cooperate more from my point of view; so we know what } \\
\text { price they are offering and agreed on a common price to sell, rather } \\
\text { than bigger companies taking advantage of their large amount of } \\
\text { products selling at a lower price." (Respondent 15) }\end{array}$ \\
\hline
\end{tabular}




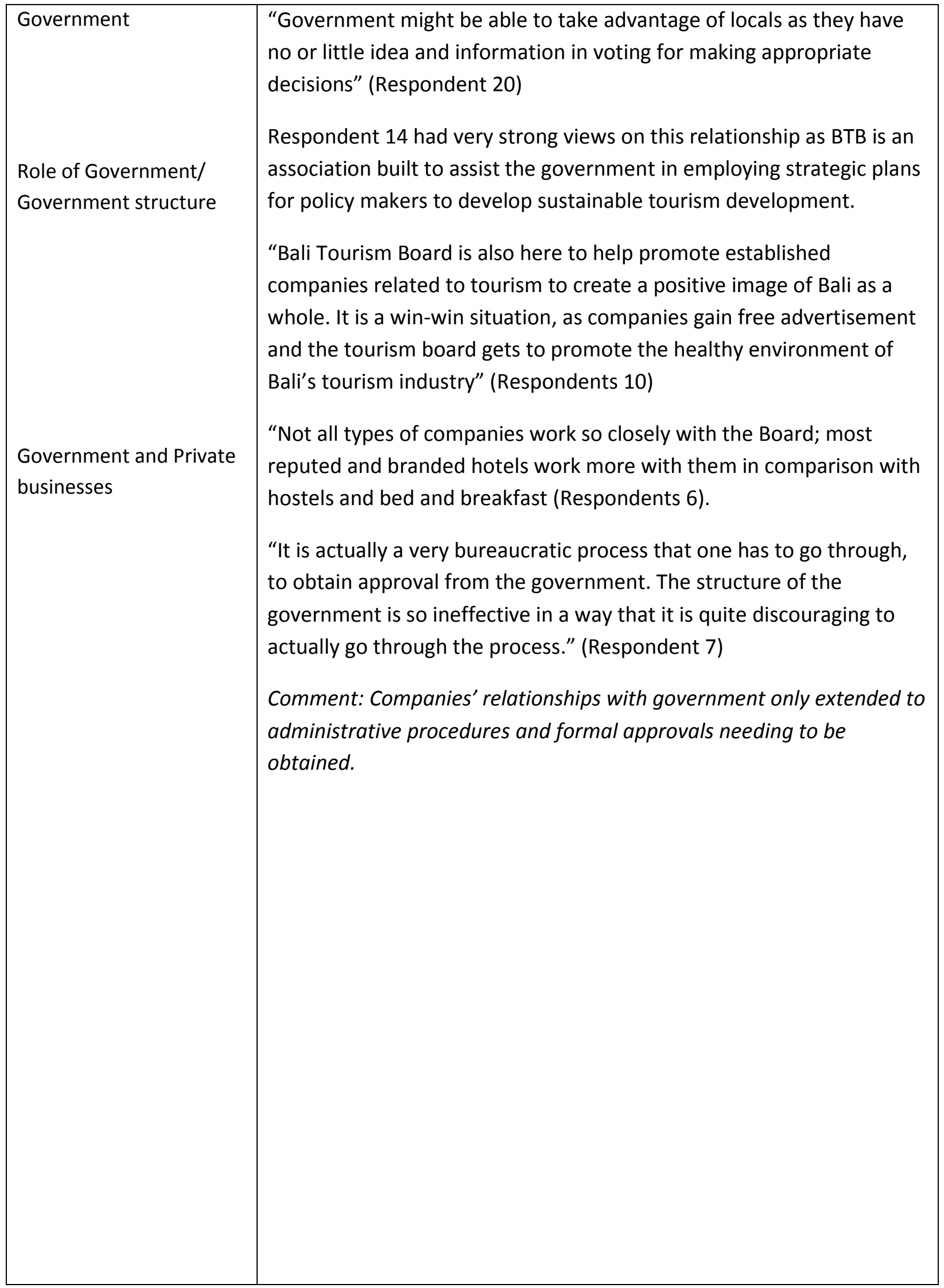


Notes.

${ }^{1}$ The term 'locals' refers to Balinese people and excludes Indonesians living there originally from other parts of Indonesia. 